\title{
Efficacy of Dexamethasone on Prevention of Post-Operative Spinal Shivering in Comparison with Intravenous Ketamine Plus Midazolam during Elective Cesarean Section
}

\author{
ISLAM B. ABD EL-HAFEZ, M.Sc.*; OSAMA ALI, M.D.** and GEHAN A. SAYED, M.D.** \\ The Department of Anesthesiology and Critical Care Medicine, Assuit Police Hospital* and Faculty of Medicine, \\ Assuit University**
}

\begin{abstract}
Background: Post-anesthetic shivering is a common complication of modem anesthesia, affecting $5-65 \%$ of patients after general anesthesia and (33\%) of patients during epidural anesthesia. Shivering can cause more server complicationin patinets with history of cardio-respiratory diseases.
\end{abstract}

Aim of Study: In this study we compared the anti-shivering effect of dexamethasone with that of ketamine plus midazolam in comparison with placebo after spinal anesthesia, in addition to evaluating any side effect of such medications.

Patients and Methods: This study was performed for 90 women ASA I, II at the age of 20-35 years with uncomplicated singleton pregnancies of more than 36 weeks gestation, who was scheduled for elective cesarean delivery under spinal anesthesia. Full medical history and examination was done to each parturient.

The patients were allocated randomly to one of three equal groups:

- Group D: Received 0. 1mg/kg dexamethasone $(\mathrm{n}=30)$.

- Group K.M: Received $0.25 \mathrm{mg}$ ketamine plus $40 \mathrm{gg}^{-1}$ midazolam $(\mathrm{n}=30)$.

- Group $S$ : Received same volume of saline $0.9 \%$ as placebo $(\mathrm{n}=30)$

Results: Our study results showed a significant decrease in the incidence of shivering among the: Ketamine plus midazolam (10\%). Group K.M.

Grade I (6.7\%), Grade II (3.3\%), Grade III (0\%), Grade IV $(0 \%)$ in comparison with the Dexamethasone (33.3\%). Group D.

Grade I (23.3\%), Grade II (6.7\%), Grade III (3.3\%), Grade IV $(0 \%)$ and Placebo (40\%). Group S.

Grade I (26.7\%), Grade II (10\%), Grade III (3.3\%), Grade IV $(0 \%)$.

The incidence of sedation was higher in females who received: Ketamine plus midazolam (26.6\%) Group K, M.

Correspondence to: Dr. Islam B. Abd El-Hafez,

The Department of Anesthesiology and Critical Care Medicine, Assuit Police Hospital
Grade I (16.6\%), Grade II (10\%) and Grade III (0\%) than Dexamethasone group (0\%) Group D and Placebo group (0\%). Group S.

Conclusion: We conclude that intravenous $(0.25 \mathrm{mg}$ ketamine plus $40 \mathrm{~g} \mathrm{~g}^{-1}$ midazolam) five min before spinal anesthesia had better anti shivering results than using intravenous $(0.1 \mathrm{mg} / \mathrm{kg}$ dexamethasone $)$ with minor side effects of such medications in women undergoing elective cesarean section.

Key Words: Post-operative spinal shivering.

\section{Introduction}

POST-ANESTHETIC shivering is a common complication of modem anesthesia, affecting 5$65 \%$ of patients after general anesthesia and (33\%) of patients during epidural anesthesia [1]. Regional anesthesia is known to significantly impair thermoregulation and predispose patients to hypothermia [2]. General and regional anesthesia alters function of autonomic nervous system which plays a significant role in thermoregulation and interferes primarily with peripheral vasoconstriction below level of sympathetic blockad [3]. Core temperature is maintained within normal range during exposure to a cool environment because of sympathetically mediated vasoconstriction [4]. Regional anesthesia produce vasodilatation which facilitates core to peripheral redistribution of heat and cool periphery is warmed at the expense of core compartment, thus hypothermia from spinal anesthesia results from redistribution of heat from the core to periphery [я. Several pharmacological agents have been studied for the treatment of PAS, including clonidine, ketamine, midazolam, dexamethasone, tramadol, and dexmedetomidine [6]. Among these agents, dexamethasone and ketamine plus midazolam have been widely used in the teatment of PAS, however, the mechanism of action of both drugs is different. 


\section{Patients and Methods}

This is a randomized double blind clinical trial carried out in Women's Health Hospital, Assiut University; between March 2015 and April 2016.

Patients: After approval by our Local Institutional Ethics Committee of the Faculty of Medicine, Assuit University. Written informed consent was obtained from all patients before participation.

This study was performed for 90 women ASA I, II at the age of 20-35 years with uncomplicated singleton pregnancies of more than 36 weeks gestation, who was scheduled for elective cesarean delivery under spinal anesthesia. Full medical history and examination was done to each parturient.

The patients were allocated randomly to one of three equal groups:

- Group D: Received $0.1 \mathrm{mg} / \mathrm{kg}$ dexamethasone $(\mathrm{n}=30)$.

- Group_K.M: Received 0.25mg ketamine plus 40 $\mu \mathrm{g} \mathrm{kg}$ midazolam $(\mathrm{n}=30)$.

- Group S: Received same volume of saline $0.9 \%$ as placebo $(\mathrm{n}=30)$.

The studied drugs was diluted with normal saline $0.9 \%$ in $20 \mathrm{ml}$ fixed volume and was administrated intravenously $5 \mathrm{~min}$ before spinal anesthesia. All the studied drugs were given to the patients by staff anesthesiologist.

\section{Anesthetic procedure:}

All patients was asked to fast for at least 6-8h pre-operatively and just before the spinal anesthesia was pre-hydrated with lactated Ringer's solution $\left(15 \mathrm{ml} \mathrm{kg}^{-1}\right)$.

Standard monitoring including continuous electrocardiogram and heart rate, pulse oximetry, noninvasive automated blood pressure measurement was recorded by anesthesia resident.

After complete aseptic technique, spinal anesthesia was induced in all cases in the lateral decubitus position. Lumbar puncture was done at L 3-4, with a 22 gauge Quincke spinal needle via a midline approach after local infiltration of the area with alkalinized $1 \%$ lidocaine $\left(0.5 \mathrm{ml} \mathrm{NaHCO}_{3}\right.$ for each $10 \mathrm{ml}$ lidocaine). The cerebrospinal fluid was aspirated, and $3 \mathrm{ml}$ of heavy bupivacaine (heavy marcaine, AstraZeneca ${ }^{\circledR}$ ) with $25 \mu \mathrm{g}$ fentanyl was injected through a spinal needle over a period of $15 \mathrm{~s}$. The spinal needle was withdrawn and the patients was repositioned supine with slight eleva- tion of the head $\left(15-20^{\circ}\right)$ for comfort. Patients wore a cotton gown and was draped with a single blanket. During the intra-operative period, all patients were completely covered in surgical drapes except for the head and neck area. No means of active warming was used. Ambient temperature of the operating rooms was maintained at $22-25^{\circ} \mathrm{C}$ with constant humidity (a room humidity of approximately 55$65 \%$ ). The sensory level was tested by pinprick sensation and the maximum level of sensory block was the highest level of disappearance of pinprick sensation reached during the study period.

Data collection: Was done by an anesthetists blind to the patient group.

1-Patient data:Demographic data of the parturients including age, weight, height, parity, duration of pregnancy were recorded.

2- Operative monitoring: Systolic Arterial Pressure (SAP), Heart Rate (HR), peripheral oxygen saturation $(\mathrm{SpO} 2)$, all measurements was recorded at baseline and then at 5, 10, 15, 20, 25, 30, 40, 50, 60, and 90min after spinal anesthesia. Ephedrine 5-10mg i.v. was administered when SAP decreased less than $90 \mathrm{mmHg}$ and repeated when needed. HR under 50 beats/min was treated with atropine $0.5 \mathrm{mg}$ i.v. Fluid resuscitation was given as follows as maintenance: First $10 \mathrm{~kg}$-* $4 \mathrm{ml} / \mathrm{kg} / \mathrm{H}$, second $10 \mathrm{~kg}-* 2 \mathrm{ml} / \mathrm{kg} / \mathrm{H}$, then remaining body weight -* $1 \mathrm{ml} / \mathrm{kg} / \mathrm{H}$ of lactated ringer solution. As fasting: Maintenance volume $\mathrm{X}$ fasting hours. 50\% in the first hour and 50\% in the second hour. Evaluating the newborn baby was done based on apgar score.

3- Shivering intensity: All measurements will be recorded at baseline and then after 5 minutes (skin incision), 15 minutes, 30 minutes (at delivery), 40 minutes (at the end of the operation), 60 minutes, and 90 minutes after spinal anesthesia.

The severity of post anesthetic shivering was assessed according to a 5 point scale $0=$ no shivering; $1=$ one or more of the following symptoms, piloerection, peripheral vasoconstriction, peripheral cyanosis without other cause, but without visible muscular activity; 2 = visible muscular activity confined to one muscle group; $3=$ visible muscular activity in more than one muscle group; $4=$ gross muscular activity including the entire body. The evaluation of patients' shivering score was carried out by an independent anesthetist unaware of patients' grouping.

Number of patients suffering from post. spinal shivering was considered as primary outcome. 
4- Degree of sedation: Sedation score $(0=$ alert, $1=$ awake but drowsy, 2 = asleep but arousable, 3 = unarousable) was measured.

5- Side effects: Any other side effects were recorded and considered as secondary outcome and properly treated e.g. nausea, vomiting, hypotension and hallucination.

Nausea and vomiting were assessed using a 3points scale $(0=$ no nausea and vomiting, $1=$ mild to moderate nausea or vomiting not needing treatment, and 3 = severe nausea or vomiting needing treatment). Patients in all groups were given intravenous dose of meperidine (10-25mg) when the drug under investigation failed to prevent shivering.

Intravenous metoclopramide $10 \mathrm{mg}$ was used to treat nausea and vomiting when needed.

6-Post-operative care: Following surgery, patients were transferred to the Post Anesthesia Care Unit (PACU) with continuous monitoring of blood pressure, heart rate and oxygen saturation.

\section{7- Statistical analysis: Sample size calculation.}

Demographic data, duration of surgery, anesthesia and time spent in PACU will be analyzed using student's test, the incidence of shivering and sedation will be analyzed using Fisher's exact test or $\chi$-test. All values are expressed as mean (SD) or as median (range). A $p$-values of $<0.05$ was considered significant.

To detect $20 \%$ reduction in the number of patients showing post.spinal shivering we need to include 30 patients in each group.

\section{Results}

This is a randomized clinical trial carried out in Women's Health Hospital, Assiut University; between March 2015 and April 2016. 90 women with ASA I, II at the age of 20-35 years with uncomplicated singleton pregnancies of more than 36 weeks gestation, who were scheduled for elective cesarean delivery under spinal anesthesia were included. They were divided into three groups to receive IV normal saline, Dexamethasone and combination of ketamine and midazolam five minutes before receiving spinal anesthesia aiming at preventing post spinal shivering. The primary outcome is number of patients suffering from post spinal shivering in each group. Secondary outcomes are any side effects in each group.

- Group D: Received $0.1 \mathrm{mg} / \mathrm{kg}$ dexamethasone $(n=30)$.
- Group k.M: Received 0.25mg ketamine plus 40 $\mathrm{kg}^{-1}$ midazolam $(\mathrm{n}=30)$.

- Group S: Received same volume of saline $0.9 \%$ as placebo $(n=30)$.

\section{Patients' data:}

The mean age of patients was $(30.3 \pm 4.1)$ years in Group S, $(29.9 \pm 3.8)$ years in Group D and (29.46 \pm 4.2$)$ years in Group K.M, with no statistically significant differences between means of the studied groups (Table 1).

Height ranged from (150-180) cm (163.2 \pm 7.3$)$

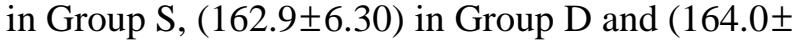
8.2) in Group K.M, with no statistically significant differences between means of the studied groups (Table 1).

Weight of patients in our study ranged from (60-90) kg, (75.9 \pm 6.93$)$ in Group S, and (75.1 \pm 11.3$)$ in Group D and (76.3 \pm 6.2$)$ in Group K.M, with no statistically significant differences between means of the studied groups (Table 1).

Duration of pregnancy ranged from (37-39) weeks, $(37.2 \pm 1.7)$ in Group S, $(37.8 \pm 0.6)$ in Group D, ( 37.5 \pm 1.8$)$ in Group K.M. No statistically significant difference was found between studied groups (Table (1).

Table (1): Patient data.

\begin{tabular}{|c|c|c|c|c|}
\hline Parameter & Group S & Group D & Group K.M. & $p$-value \\
\hline - Age (years) & $30.3 \pm 4.1$ & $29.9 \pm 3.8$ & $29.46 \pm 4.2$ & 0.629 \\
\hline - Weight (Kg) & $75.9 \pm 6.93$ & $75.1 \pm 11.3$ & $76.3 \pm 6.2$ & 0.544 \\
\hline - Height $(\mathrm{Cm})$ & $163.2 \pm 7.3$ & $162.9 \pm 6.30$ & $164.0 \pm 8.2$ & 0.725 \\
\hline $\begin{array}{l}\text { - Duration of } \\
\text { pregnancy (weeks) }\end{array}$ & $37.2 \pm 1.7$ & $37.8 \pm 0.6$ & $37.5 \pm 1.8$ & 0.622 \\
\hline
\end{tabular}

Operative data:

Duration of operation was $(41.7 \pm 5.3)$ minutes in Group S, $(42.5 \pm 6.2)$ minutes in Group D and (43.9 \pm 7.1$)$ minutes in Group K.M. No statistically significant difference was found between studied groups (Table 2).

Blood loss was $(384.6 \pm 75.3) \mathrm{ml}$ in Group $\mathrm{S}$, $(375.35 \pm 62.1) \mathrm{ml}$ in Group D and (375.35 \pm 62.1$)$ $\mathrm{ml}$ in Group K.M. No statistically significant difference was found between studied groups (Table 2).

Fluid infused during operation was $(2.2 \pm 0.3)$ L in Group S, $(2.3 \pm 0.2)$ L in Group D and $(2.1 \pm 0.3)$ L in Group K.M. No statistically significant difference was found between studied groups (Table 2). 
Total dose of ephedrine which was given during operation was $(11.1 \pm 13.2) \mathrm{mg}$ in Group S, (13.5 \pm 13.6) $\mathrm{mg}$ in Group D and (11.8 \pm 16.4$) \mathrm{mg}$ in Group K.M. No statistically significant difference was found between studied groups (Table 2).

Table (2): Operative data.

\begin{tabular}{lllll}
\hline Parameter & Group S & Group D & \multicolumn{2}{l}{ Group K.M. $\boldsymbol{p}$-value } \\
\hline - Duration of & $41.7 \pm 5.3$ & $42.5 \pm 6.2$ & $43.9 \pm 7.1$ & 0.433 \\
$\quad \begin{array}{l}\text { operation (minutes) } \\
\text { - Blood loss (ml) }\end{array}$ & $384.6 \pm 75.3$ & $367.1 \pm 81.3$ & $375.35 \pm 62.1$ & 0.671 \\
- Fluid (L) & $2.2 \pm 0.3$ & $2.3 \pm 0.2$ & $2.1 \pm 0.3$ & 0.224 \\
- Ephedrine (mg) & $11.1 \pm 13.2$ & $13.5 \pm 13.6$ & $11.8 \pm 16.4$ & 0.326 \\
\hline Group S: Saline. & & & & \\
Group D: Dexamethasone. & & & \\
Group K.M: Ketamine + Midazolam. &
\end{tabular}

\section{Shivering and sedation:}

Shivering occurred in 12 out of 30 patients in the control group (40.0\%), (8 patients Grade I/3 patients Grade II/1 patient Grade III/0 patient Grade IV) in 10 out of 30 patients in Dexamethasone group (33.3\%).

( 7 patients Grade I/2 patients Grade II/1 patient Grade III/0 patient Grade IV) and in only 3 out of 30 patients in Ketamine and midazolam group $(10 \%)$.

(2 patients Grade I/1 patients Grade II/0 patient Grade III/0 patient Grade IV).

Chi square test revealed a statistically significant difference between the Group K.M and other two groups while there was no significant difference between the Group S and Group D (Table 3), Figs. $(1,2)$.

Sedation was noticed only in Ketamine and midazolam group 8 patients $(26.7 \%)$, (5 patients with Grade I, while 3 patients with Grade II, 0 patients with Grade III).

Showing high significant difference to other two groups with no significant difference between Groups S and Group D (Table 3), Fig. (3).

Table (3): Shivering and sedation.

\begin{tabular}{cllcc}
\hline Parameter & Group S & Group D & Group K.M. & $p$-value \\
\hline Shivering: & $12 / 30$ & $10 / 30$ & $3 / 30$ & 0.029 \\
Grade I & 8 & 7 & 2 & \\
Grade II & 3 & 2 & 1 & \\
Grade III & 1 & 1 & 0 & \\
Grade IV & 0 & 0 & 0 & $<0.001$ \\
Sedation: & $0 / 30$ & $0 / 30$ & $8 / 30$ & \\
Grade I & 0 & 0 & 5 & \\
Grade II & 0 & 0 & 3 & \\
Grade III & 0 & 0 & 0 & \\
\hline$p$-value $<0.05$ considered significant. &
\end{tabular}

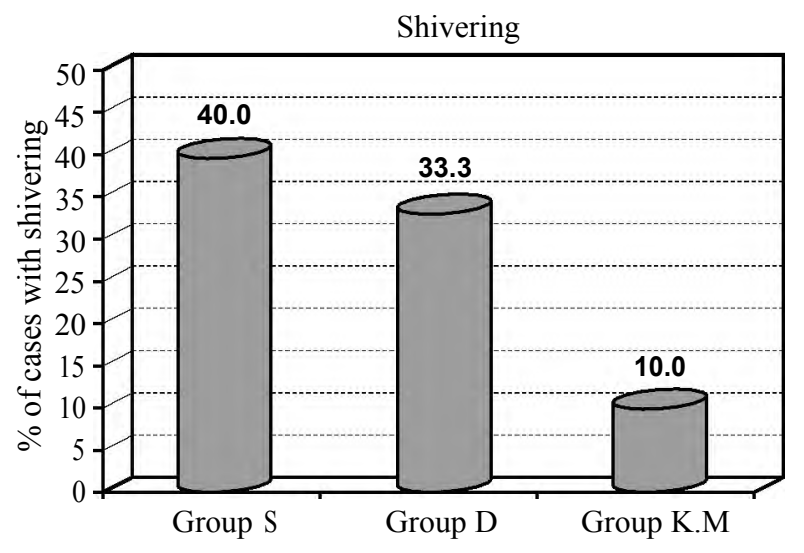

Fig. (1): Shivering.

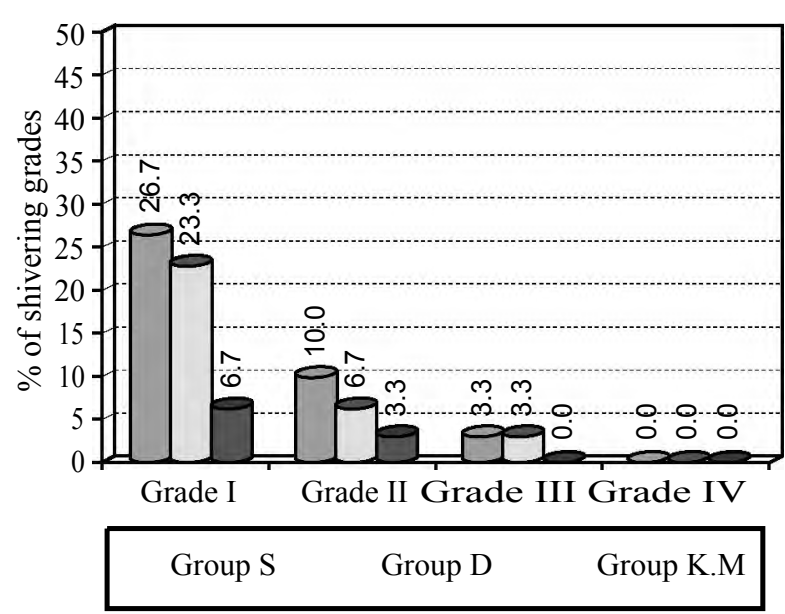

Fig. (2): Shivering grades.

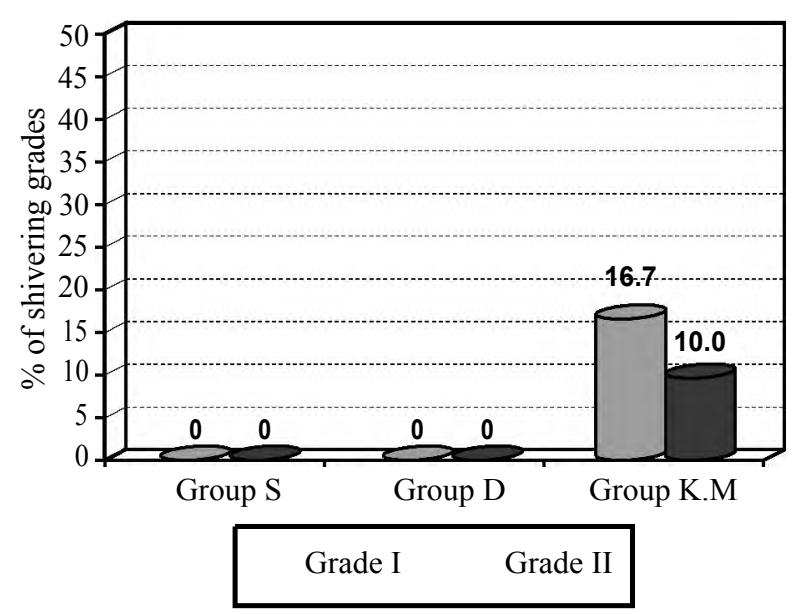

Fig. (3): Sedation.

\section{Peripheral body temperature changes:}

Baseline peripheral body temperature in the studied groups ranged from $(36.5 \pm 0.3)$ to $(36.8 \pm$ 0.3 ) Celsius with no statistically significant difference between them at all times of the study (Table 4), Fig. (4). There was no significant decrease in peripheral body temperature in all studied groups at all different times of delivery compared to baseline value. 
Table (4): Peripheral body temperature changes $\left({ }^{\circ} \mathrm{C}\right)$.

\begin{tabular}{lcccc}
\hline Parameter & Group S & Group D & Group K.M. & $p$-value \\
\hline - Baseline & $36.6 \pm 0.4$ & $36.7 \pm 0.4$ & $36.7 \pm 0.36$ & 0.622 \\
- At skin incision & $36.6 \pm 0.4$ & $36.6 \pm 0.4$ & $36.6 \pm 0.33$ & 0.641 \\
$\quad$ (after 5mins) & & & & \\
- After 15mins & $36.5 \pm 0.4$ & $36.5 \pm 0.3$ & $36.5 \pm 0.3$ & 0.889 \\
- At delivery (after & $36.6 \pm 0.5$ & $36.6 \pm 0.5$ & $36.5 \pm 0.4$ & 0.522 \\
$\quad$ 30mins) & & & & \\
- At the end of the & $36.7 \pm 0.4$ & $36.7 \pm 0.7$ & $36.7 \pm 0.6$ & 0.487 \\
operation (after & & & & \\
40mins) & & & & \\
- After 60mins & $36.8 \pm 0.3$ & $36.7 \pm 0.3$ & $36.8 \pm 0.3$ & 0.766 \\
- After 90mins & $36.8 \pm 0.3$ & $36.8 \pm 0.2$ & $36.8 \pm 0.3$ & 0.575 \\
\hline
\end{tabular}

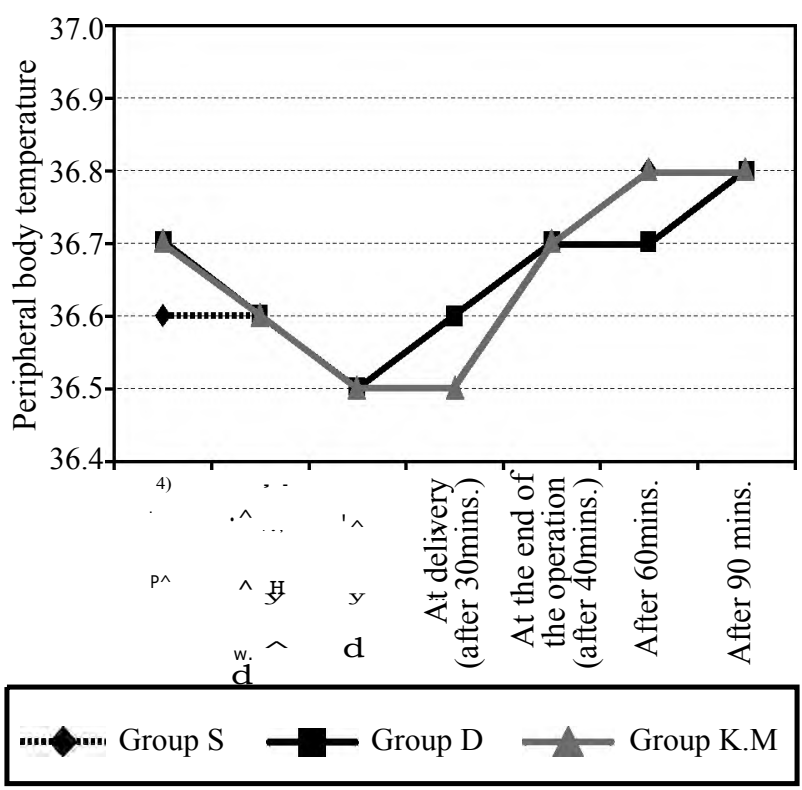

Fig. (4): Peripheral body temperature changes $\left({ }^{\circ} \mathrm{C}\right)$.

\section{Heart rate changes:}

Baseline heart rate in the three studied groups ranged from $86.33 \pm 7.05$ to $102.15 \pm 21.28$ beats $/ \mathrm{min}$. with no statistically significant difference between studied groups at all times of the study except after 15 mins ( $p$-value 0.025) (Table 5), Fig. (5).

There was significant decrease in heart rate at Group $\mathrm{S}$ at skin incision, at the end of the operation, after $60 \mathrm{mins}$ and after $90 \mathrm{mins}(p$-value $<0.05)$ compared to baseline value (Table 5), Fig. (5).

There was significant decrease in heart rate at Group D at the end of the operation, after $60 \mathrm{mins}$ and after $90 \mathrm{mins}(p$-value $<0.05)$ compared to baseline value (Table 5), Fig. (5).

There was significant decrease in heart rate at Group k.M after $60 \mathrm{mins}$ and after $90 \mathrm{mins}$ ( $p$-value $<0.05$ ) compared to baseline value (Table 5), Fig. (5).
Table (5): Heart rate changes (beats/min).

\begin{tabular}{lllll}
\hline Parameter & Group S & Group D & Group K.M. & $p$-value \\
\hline - Baseline & $99.3 \pm 23.8$ & $102.15 \pm 21.28$ & $98.43 \pm 13.39$ & 0.492 \\
- At skin & $90.8 \pm 20.49^{*}$ & $100.55 \pm 24.31$ & $95.35 \pm 16.97$ & 0.442 \\
incision (after & & & & \\
$\begin{array}{l}\text { 5mins) } \\
\text { - After 15mins }\end{array}$ & $96.76 \pm 18.33$ & $99.25 \pm 20.67$ & $101.04 \pm 14.96$ & 0.025 \\
- At delivery & $92.64 \pm 13.91$ & $93.85 \pm 26.14$ & $95.52 \pm 12.28$ & 0.066 \\
(after 30mins) & & & & \\
- At the end of & $88.09 \pm 9.46^{*}$ & $93.80 \pm 11.94^{*}$ & $94.70 \pm 15.83$ & 0.06 \\
the operation & & & & \\
(after 40mins) & & & & \\
- After 60mins & $87.55 \pm 9.01 *$ & $92.40 \pm 10.55^{*}$ & $89.43 \pm 7.60^{*}$ & 0.165 \\
- After 90mins & $86.33 \pm 7.05^{*}$ & $90.25 \pm 7.69 *$ & $87.74 \pm 7.01 *$ & 0.185 \\
\hline$p$-value $<0.05$ considered significant. & &
\end{tabular}

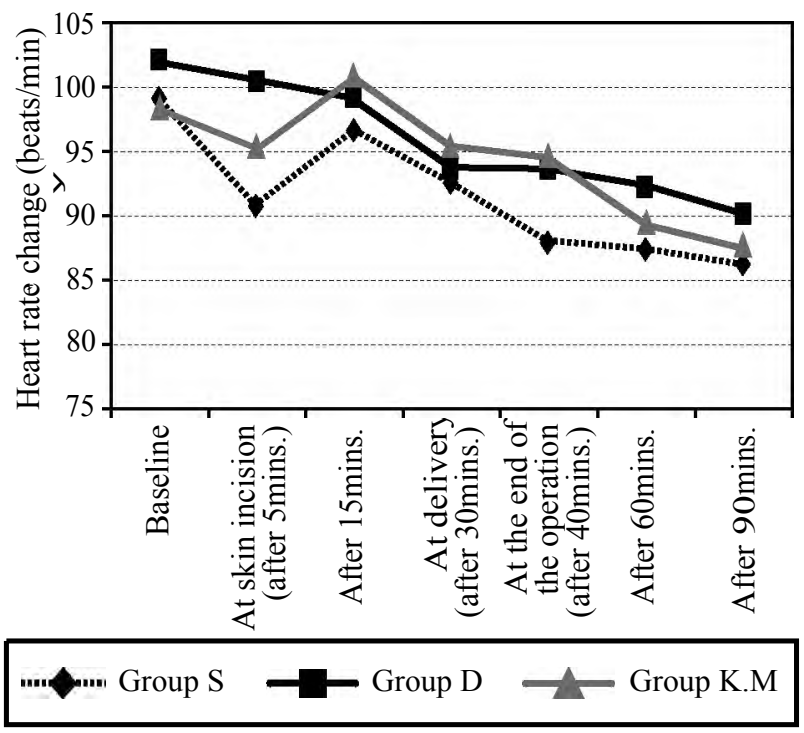

Fig. (5): Heart rate changes.

Mean Arterial Pressure changes (MAP):

Baseline MAP in the three studied groups ranged from $70.39 \pm 13.79$ to $80.18 \pm 10.03 \mathrm{~mm} . \mathrm{Hg}$. With no statistically significant difference between studied groups at all times of the study (Table 6), Fig. (6). There was no significant difference in MAP at all studied groups compared to baseline values at different times of the study (Table 6), Fig. (6).

Table (6): Mean arterial pressure changes in the three studied groups (mm.Hg).

\begin{tabular}{lcccc}
\hline Parameter & Group S & Group D & \multicolumn{2}{c}{ Group K.M. $\boldsymbol{p}$-value } \\
\hline - Baseline & $75.06 \pm 16.51$ & $77.00 \pm 14.37$ & $74.70 \pm 14.77$ & 0.73 \\
- At skin & $72.09 \pm 15.35$ & $70.45 \pm 13.36$ & $70.39 \pm 13.79$ & 0.606 \\
$\quad$ incision (after & & & & \\
$\begin{array}{l}\text { 5mins) } \\
\text { - After 15mins }\end{array}$ & $76.30 \pm 13.85$ & $71.00 \pm 15.66$ & $73.48 \pm 15.01$ & 0.233 \\
- At delivery & $75.56 \pm 12.47$ & $74.30 \pm 11.14$ & $75.26 \pm 11.00$ & 0.937 \\
(after 30mins) & & & & \\
- At the end of & $78.58 \pm 10.64$ & $74.25 \pm 8.53$ & $74.78 \pm 7.50$ & 0.298 \\
the operation & & & & \\
(after 40mins) & & & & \\
- After 60mins & $79.00 \pm 9.71$ & $76.40 \pm 7.30$ & $76.09 \pm 8.83$ & 0.59 \\
- After 90mins & $80.18 \pm 10.03$ & $77.15 \pm 6.28$ & $77.35 \pm 8.18$ & 0.497 \\
\hline
\end{tabular}

$p$-value $<0.05$ considered significant. 


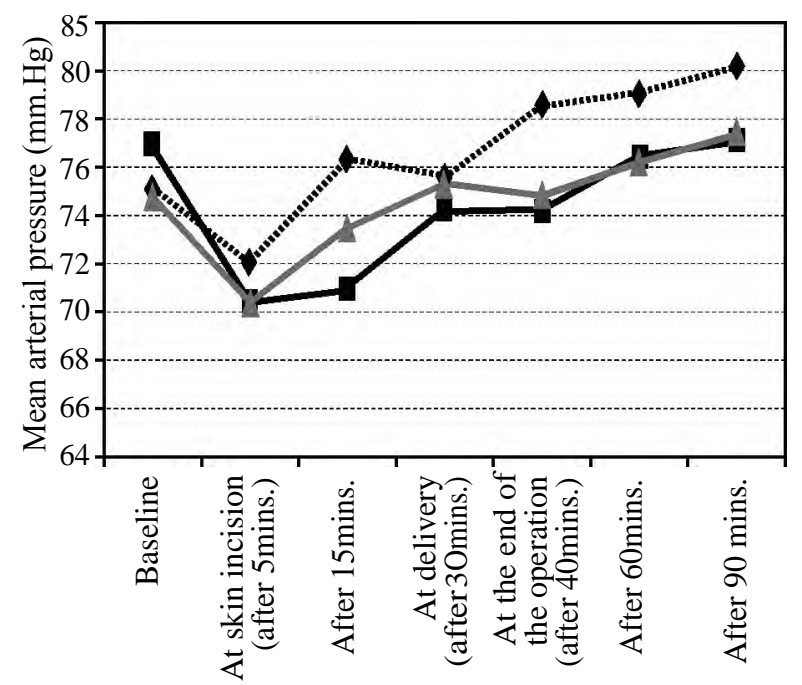

-...... Group S Group D $\longrightarrow$ Group K.M

Fig. (6): Mean arterial blood pressure.

\section{Respiratory rate changes:}

There were no statistically significant differences in the R.R at different times of the study between the three studied groups (Table 7), Fig. (7). There was significant decrease in respiratory rate at Group S ( $p$-value <0.05), Group K.M ( $p$ value $<0.05)$ after $15 \mathrm{mins}$ compared to baseline value (Table 7), Fig. (7). There was significant decrease in respiratory rate at Group D at after $60 \mathrm{mins}$ ( $p$-value $<0.05$ ) compared to baseline value (Table 7), Fig. (7).

\section{Peripheral oxygen saturation changes:}

There were no statistically significant differences as regard peripheral oxygen saturation at different times of the study between the studied groups (Table 8), Fig. (8). There were no statistically significant differences at all studied groups compared to baseline value at all times of the study (Table 8), Fig. (8).

Table (7): Respiratory rate changes (breath/min).

\begin{tabular}{|c|c|c|c|c|}
\hline Parameter & Group $S$ & Group D & Group K.M. & $p$-value \\
\hline - Baseline & $18.79 \pm 1.65$ & $18.40 \pm 1.27$ & $18.30 \pm 1.33$ & 0.671 \\
\hline $\begin{array}{l}\text { - At skin } \\
\text { incision (after } \\
\text { 5mins) }\end{array}$ & $18.15 \pm 1.39$ & $18.25 \pm 1.48$ & $17.87 \pm 1.14$ & 0.582 \\
\hline - After $15 \mathrm{mins}$ & $17.88 \pm 1.60^{*}$ & $17.65 \pm 1.39$ & $17.52 \pm 1.27^{*}$ & 0.647 \\
\hline $\begin{array}{l}\text { - At delivery } \\
\quad \text { (after 30mins) }\end{array}$ & $18.42 \pm 1.70$ & $18.00 \pm 1.21$ & $18.22 \pm 0.85$ & 0.917 \\
\hline $\begin{array}{l}\text { - At the end of } \\
\text { the operation } \\
\text { (after 40mins) }\end{array}$ & $18.12 \pm 1.02$ & $17.90 \pm 0.91$ & $17.96 \pm 1.11$ & 0.833 \\
\hline - After $60 \mathrm{mins}$ & $18.33 \pm 1.08$ & $17.70 \pm 0.86^{*}$ & $18.09 \pm 1.31$ & 0.316 \\
\hline - After 90mins & $18.36 \pm 1.19$ & $17.85 \pm 0.93$ & $18.30 \pm 1.22$ & 0.469 \\
\hline
\end{tabular}

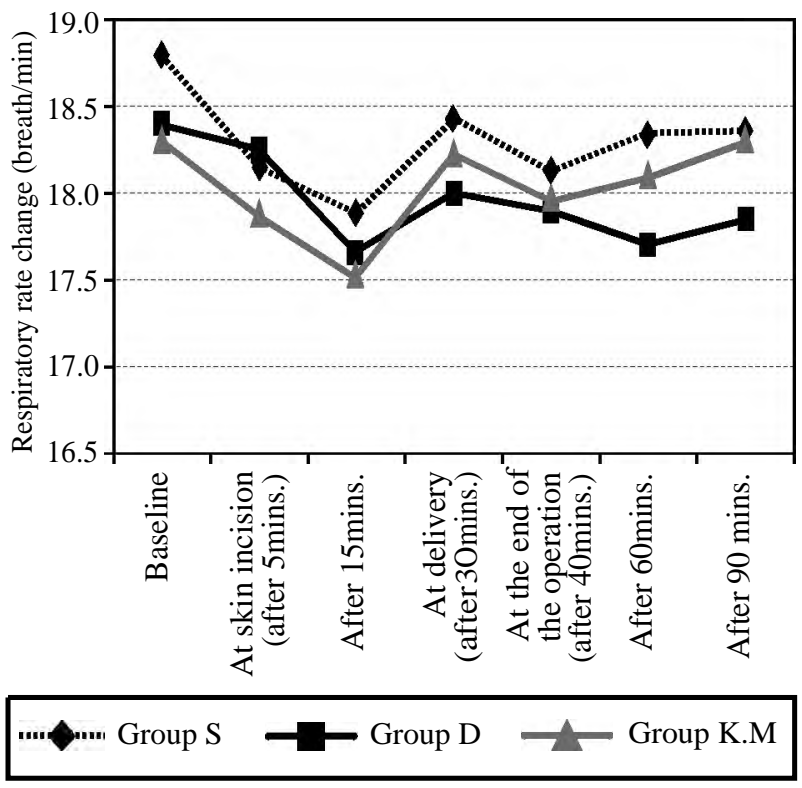

Fig. (7): Respiratory rate changes.

Table (8): Peripheral oxygen saturation changes groups (\%).

\begin{tabular}{lcccc}
\hline Parameter & Group S & Group D & Group K.M. & $p$-value \\
\hline - Baseline & $98.79 \pm 0.99$ & $99.30 \pm 0.66$ & $99.09 \pm 0.90$ & 0.125 \\
- At skin & $98.91 \pm 0.91$ & $98.95 \pm 1.15$ & $99.00 \pm 0.99$ & 0.627 \\
$\begin{array}{l}\text { incision (after } \\
\text { 5mins) }\end{array}$ & & & & \\
- After 15mins & $98.61 \pm 1.09$ & $98.85 \pm 1.14$ & $98.57 \pm 1.08$ & 0.477 \\
- At delivery & $98.88 \pm 1.02$ & $99.05 \pm 0.89$ & $98.83 \pm 1.11$ & 0.346 \\
$\quad$ (after 30mins) & & & & \\
- At the end of & $99.03 \pm 0.68$ & $98.95 \pm 0.94$ & $98.87 \pm 0.92$ & 0.481 \\
the operation & & & & \\
- after 40mins) & & & & \\
- After 60mins & $98.91 \pm 0.63$ & $98.90 \pm 0.97$ & $98.82 \pm 0.83$ & 0.607 \\
- After 90mins & $98.91 \pm 0.68$ & $98.95 \pm 0.94$ & $99.04 \pm 0.82$ & 0.687 \\
\hline
\end{tabular}

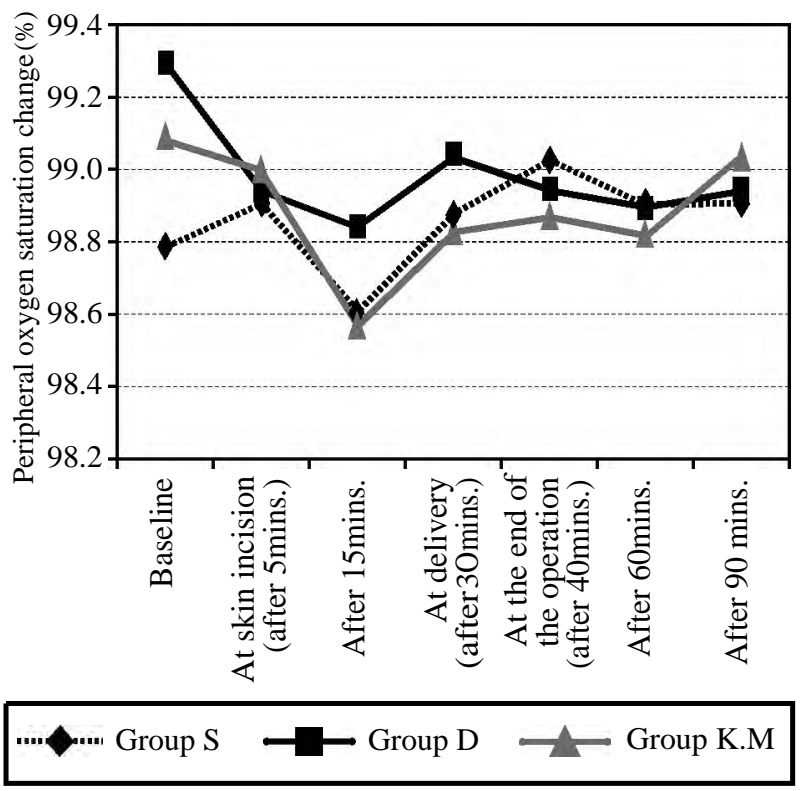

Fig. (8): Peripheral oxygen saturation (\%). 


\section{Apgar score:}

Our study shows that all studied groups had normal Apgar score.

\section{Side effects and complications:}

No side effects as nausea, vomiting and hallucination were noticed in any case of study groups at all the times of the study even in KM Group.

\section{Discussion}

In this study anti-shivering measures given preoperatively to patients undergoing elective cesarean section demonstrated that using intravenous $(0.25$ mg ketamine plus $40 \mu \mathrm{g} \mathrm{kg}^{-1}$ midazolam) five min before spinal anesthesia had the best anti shivering results than using intravenous $(0.1 \mathrm{mg} / \mathrm{kg}$ dexamethasone) at the same time before spinal anesthesia.

All patients was asked to fast for at least 6-8h pre-operatively and just before the spinal anesthesia was pre-hydrated with lactated Ringer's solution $\left(15 \mathrm{ml} \mathrm{kg}^{-1}\right)$.

An important goal of modern anesthesia is not only to provide balanced anesthesia but also to provide quality control of postoperative shivering which affects $5-65 \%$ of patients after general anesthesia and (33\%) of patients during spinal/ epidural anesthesia.

Post anesthetic shivering may cause discomfort to the patient, aggravates wound pain by stretching incision, increase intraocular pressure and increase intracranial pressure [7].

Shivering also increase tissue oxygen demand by as much as $500 \%$ and accompanied by increase in minute ventilation and cardiac output to maintain aerobic metabolism. This may be deleterious in patient with impaired cardiovascular reserve or a limited respiratory capacity. Shivering may also interfere with the monitoring of patients by causing artifacts of electrocardiography, blood pressure and pulse oximetry [8].

Our study results showed a significant decrease in the incidence of shivering among the:

Ketamine plus midazolam (10\%). Grade I (6.7\%) Grade II (3.3\%) Grade III (0\%) Grade IV $(0 \%)$ in comparison with the Dexamethasone (33.3\%). Grade I (23.3\%) Grade II (6.7\%) Grade III $(3.3 \%)$ Grade IV (0\%) and Placebo (40\%). Grade I (26.7\%) Grade II (10\%) Grade III (3.3\%) Grade IV (0\%).
The incidence of sedation was higher in females who received:

Ketamine plus midazolam (26.6\%) Grade I (16.6\%) Grade II (10\%) and Grade III (0\%) than Dexamethasone group (0\%) and Placebo group $(0 \%)$.

Our results are in agreements with Masood Entezariasl and Khatereh Isazadehfar at 2013 (compared between dexamethazone and pethidine in 120 ASA I and II patients who underwent orthopedic, ENT and general surgery under general anesthesia) who reported that the shivering incidence rate in the control group was $47.5 \%$. While in the dexamethasone group this rate was reduced to $10 \%$ and to $37.5 \%$ in the pethidine. This study demonstrates that the use of dexamethasone can also reduce the incidence of shivering, even more than pethidine. Statistically, there was a significant difference between the groups of dexamethasone and pethidine.

Dexamethasone is the type of steroid medication. It has anti-inflammatory and immunosuppressant effects. It is 25 times more potent than cortisol in its glucocorticoid effect while having minimal mineralocorticoid effect $[9,10]$

Dexamethasone reduce gradient between skin and body core temperature.

It could reduce shivering by regulating immune response [11]

Also our results are in agreements with B. Shakya et al., 2010 founded that the prophylactic administration of low dose ketamine $\left(0.25 \mathrm{mg} \mathrm{kg}^{-1}\right)$ and ondansetron $(4 \mathrm{mg})$ produces significant antishivering effect in comparison to placebo, in 120 ASA I and II patients undergoing lower abdominal surgery under spinal anaesthesia without any_significant side effects. Ketamine $\left(0.25 \mathrm{mg} \mathrm{kg}^{-1}\right)$ is significantly more effective than ondansetron $(4 \mathrm{mg})$ during spinal anaesthesia.

Ketamine which is a competitive receptor antagonist of N-methyl-D-aspartic Acid (NMDA) has a role in thermoregulation by different means [12] NMDA receptor acts by modulating the noradrenergic and serotoninergic neurons in the locus ceroleus [13]. And modulate ascending nociceptive transmission at the dorsal horn of the spinal cord [14] Ketamine controls shivering by non-shivering thermogenesis either by the action on the hypothalamus or by the B-adrenergic effect of Norepinephrine [15]. 
Another agreements with study done by Honarmand and Safavi at 2008 midazolam $37.5 \mu \mathrm{g} / \mathrm{kg}$ combined with ketamine $0.25 \mathrm{mg} / \mathrm{kg}$ in $120 \mathrm{ASA}$ I and II patients under went orthopedic surgery under spinal anesthesia. Peripheral body temperature did not show any changes when the two drugs were combined. In their study, prophylactic use of ketamine combined with midazolam was more effective than ketamine or midazolam IV in prevention of shivering in patients undergoing regional anesthesia.

Benzodiazepines have been found to reduce repetitive firing in response to depolarizing pulses in mouse spinal cord neurons [16]. This function may be responsible for suppressing shivering. Among benzodiazepines, diazepam has been found to be effective in the prevention of postspinal shivering [17]. It produces minimal impairment of thermoregulatory control.

According to the sedation score we used in the study:

We found that ketamine plus midazolam had more sedative effect Grade I and II and 8/30 females showed criteria of sedation $(26.6 \%)$ than other groups these results were consistent with Honarmand and Safavi at 2008 study that showed that sedation score was significantly higher in midazolam group (Grade I), than ketamine-midazolam group (Grade I) and control group (Grade I), and was higher in ketamine group (Grade II) than in control group (Grade I).

There was no difference among the three groups in relation to hemodynamic parameters. These results were consistent with previous studies by $[18,19]$.

The other significant finding of our study was that no complications like nausea, vomiting, hypotension and hallucinations was seen in the three groups.

\section{Conclusion:}

We conclude that intravenous $(0.25 \mathrm{mg}$ ketamine plus $40 \mu \mathrm{g} \mathrm{kg}^{-1}$ midazolam) five min before spinal anesthesia had better anti shivering results than using intravenous $(0.1 \mathrm{mg} / \mathrm{kg}$ dexamethasone $)$ with minor side effects of such medications in women undergoing elective cesarean section.

\section{References}

1- ADAM R.D., VICTOR M. and ROPPER A.H.: Motor paralysis. In: Adam R.D., Victor M., Ropper A.H., eds. Principles of Neurology, 6 th Edn. New York: McGraw Hill Inc., 45-63, 1997.
2- BOCK M., SINNER B., GÖTTLICHER M., SIMON E., MARTIN E. and MOTSCH J.: Involvement of serotonergic pathways in postanaesthetic cold defence: Dolasetron prevents shivering. J. Therm. Biol., 27: 159-66, 2002.

3- CHEONG K.F.1, CHEN F.G. and YAU G.H.: Postanaesthetic shivering a comparison of thiopentone and propofol Anaesthesia, Sep., 27 (5): 729-32, 1998.

4- CROWLEY L.J. and BUGGY D.J.: Shivering and neuraxial anesthesia. Reg. Anesth. Pain Med., 33: 241-52, 2008.

5- DAL D., KOSE A., HONCA M., AKINCI B., BASGUL E. and AYPAR U.: Efficacy of prophylactic ketamine in preventing post-operative shivering. Br. J. Anaesth., 95: 189-92, 2005.

6- De WITTE J. and SESSLER D.I.: Perioperative shivering: Physiology and pharmacology. Anesthesiology, 96: 46784, 2002.

7- DeWITTE J., DELOOF T., DeVEYLDER J. and HOUSMANS P.R.: Tramadol in the treatment of postanesthetic shivering. Acta Anaesthesiol. Scand., 41: 506-10, 1997.

8- FRANK S.M., BEATTIE C., CHRISTOPHERSON R., et al.: Epidural versus general anesthesia, ambient operating room temperature, and patient age as predictors of inadvertent hypothermia. Anesthesiology, 77: 252-7, 1992.

9- GOOLD J.E.: Post-operative spasticity and shivering. A review with personal observations of 500 patients. Anaesthesia, 39: 35-8, 1984.

10- GROVER V.K., MAHAJAN R., YADDANAPUDI L.N., SUDARSHANA H.G. and GILL K.D.: Efficacy of midazolam in preventing post-operative shivering. Int. J. Clin. Pharmacol. Ther., 40: 534-6, 2002.

11- HENDOLIN H. and LANSIMIES E.: Skin and central temperatures during continuous epidural analgesia and general anaesthesia in patients subjected to open prostatectomy. Ann. Clin. Res., 14: 181-6, 1982.

12- HONARMAND A. and SAFAVI M.R.: Comparison of prophylactic use of midazolam, ketamine, and ketamine plus midazolam for prevention of shivering during regional anaesthesia: A randomized double-blind placebo controlled trial. Br. J. Anaesth., 101: 557-62, 2008.

13- HORN E.P., STANDL T., SESSLER D.I., et al.: Physostigmine prevents post-anesthetic shivering as does meperidine or clonidine. Anesthesiology, 88: 108-13, 1998.

14- IKEDA T., KAZAMA T., SESSLER D.I., et al.: Induction of anesthesia with ketamine reduces the magnitude of redistribution hypothermia. Anesth. Analg., 93: 934-8, 2001.

15- JORIS J., BANACHE M., BONNET F., SESSLER D.I. and LAMY M.: Clonidine and ketanserin both are effective treatment for postanesthetic shivering. Anesthesiology, 79: 532-9, 1993.

16- KELSAKA E., BARIS S., KARAKAYA D. and SARIHASAN B.: Comparison of ondansetron and meperidine for prevention of shivering in patients undergoing spinal anesthesia. Reg. Anesth. Pain Med., 31: 40-5, 2006. 
17- KELSAKA E., BARIS S., KARAKAYA D. and SARıHASAN B.: Comparison of ondansetron and meperidine for prevention of shivering in patients undergoing spinal anesthesia. Reg. Anesth. Pain Med., 1: 40-5, 2006.

18-KINOSHITA T., SUZUKI M., SHIMADA Y. and OGAWA R.: Effect of low-dose ketamine on redistribution hypo- thermia during spinal anesthesia sedated by propofol. J. Nippon. Med. Sch., 71: 92-8, 2004.

19-KRANKE P., EBERHART L.H., ROEWER N. and TRAMER M.R.: Pharmacological treatment of post-operative shivering: A quantitative systematic review of randomized controlled trials. Anesth. Analg., 94: 453-60, 2002.

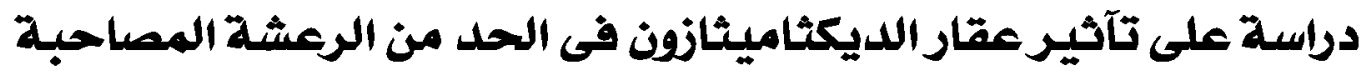

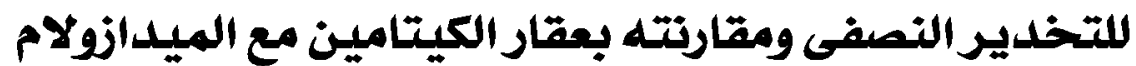

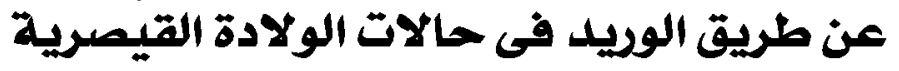

عملية الإرتعاش كاتثر جانبى بعد التخدير النصفى آو الكلى آثناء الجراحات هى عملية شائعة وتختلف من مريض إلى آخر وتعتمد على النوع

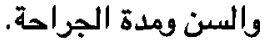

وتعرف عملية الإرتعاش بآنها الحركة اللاإرادية لعضلة آو آكثر والتى تصدث بعد فترة تصيرة من التخدير الكلى آو النصفى وهذه الحركة تصدث بنسبة ح\% إلى 170\%

وقد تم دراسة العديد من العقارات لعلاج هذا الآثر الجانبى ومنها (الكيتامين - الميدازولام- الديكاميثانون - الديكثاميديتوميدين - كلوندين

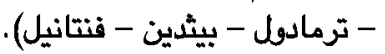

وقد تتسبب هذه الرعشة ف عدم راحة للمريض وقد تسبب العديد من المضاعفات ف المرضى ذوى التاريخ المرضى بآمراض القلب والجاهز

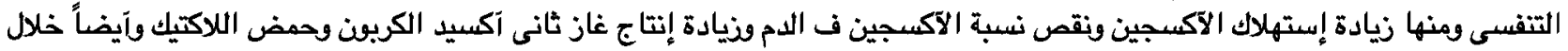

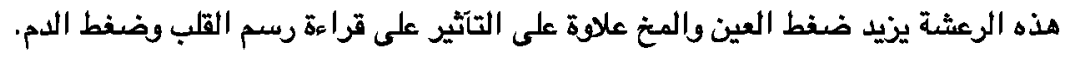

من ضمن العقارات والتى تستخدم بكثرة فى العلاج عقار الديكثاميثانفن وعقار الكيتامين مع الميانولام وإكن هناك إختلاف فى طريق عمل كل منهم.

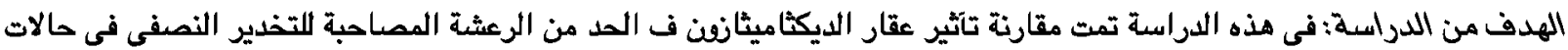

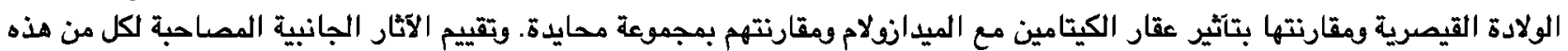
العقارات.

طريقة العمل والمرضى: بعد موافقة لجنة الآخلاقيات المؤسسية المحلية الخاصة بكلية الطب جامعة آسيوط تم آخذ موافقة مكتوبة من المريض على إجراء الدراسة عليه قبل ممارستها.

تم تحديد عدد تسعون سيدة واللاتى خططن للقيام بولادة قيصرية وتم تقسيمهم عشوائيا إلى ثلاث مجموعات كل مجموعة تتضمن ثلاثقن مجموعة د: تم إعطائها ـ امل ج/كجم ديكثاميثارن.

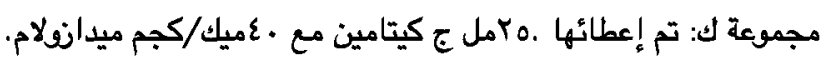
مجموعة س: تم إعطائها محلول ملح .9\% كمجموعة محايدة.

تم تقسيم السيدات بطريقة عشوائية عن طريق آرقام بواسطة الكمبيوتر عن طريق آظرف مغلقة والتى تم فتحها بدا الدراسة مباشرة لكل

تم تخفيف العقارات ف محلول ملح .9٪ فى حجم ثابت وهو .rمللى وتم إعطائها عن طريق الويد قبل التخدير النصفى ب خمسة دقائق وتم إعطائها عن طريق طبيب التخدير بنفسه.

عملية التخدير :تم التبيه ع الحلات بالصيام المدة لا تقل عن ^ ساعات قبل العملية القيصرية وتم إعطائها قبل التخدير النصفى محلول رينجر امللى/كجم. 


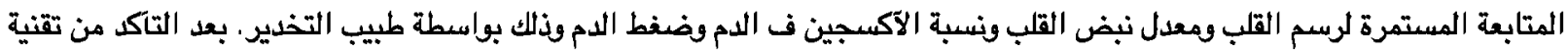

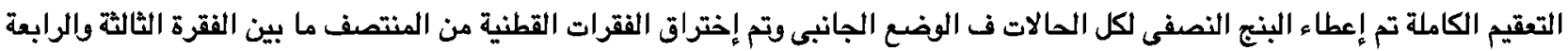

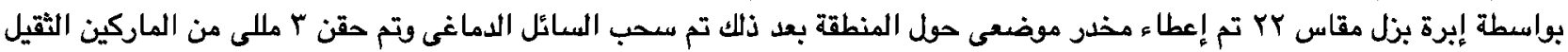

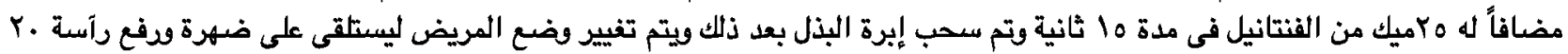

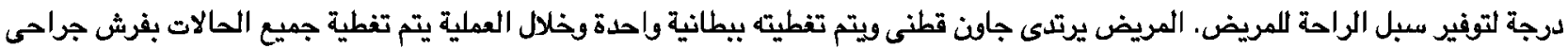

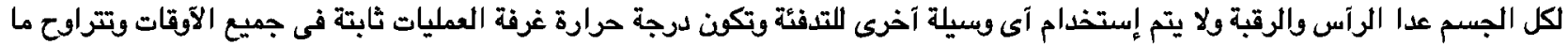

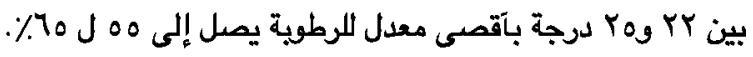

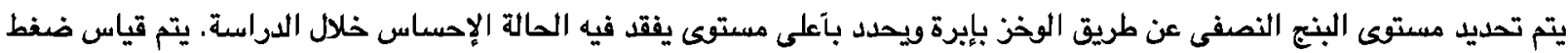

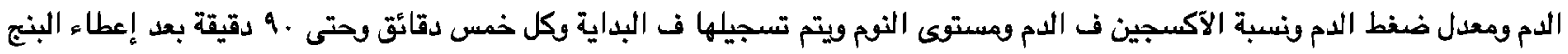

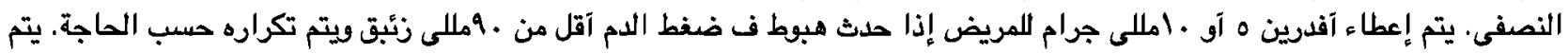

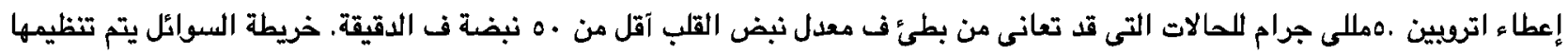

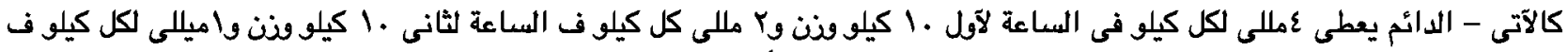

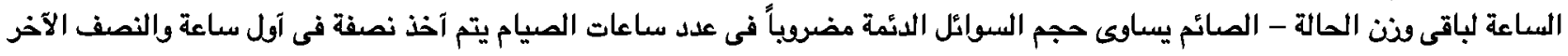
فن العياعة الثاثية.

يتم تحديد شَدة الرعشّة عن طريق منظومة من 0 نقاط كالآتى: • لا يوجد رعشة = •

واحدة من الآعراض الآتية (إنتصاب الشعر - تضيق الآوعية الدموية فى الآطراف - إزرقاق فى الآطراف من غير آسباب = () وذلك بلون نشاط عضلى ملحوظ.

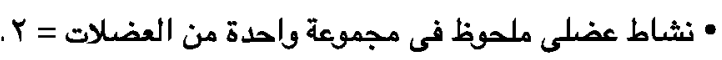

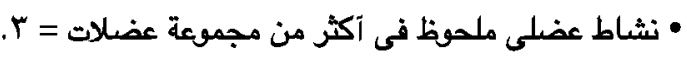

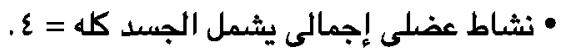

يتم تحديد درجة الإرتعاش بواسطة طبيب تخدير لا يعلم بالمجموعة التى تنتمى إليها الحالة.

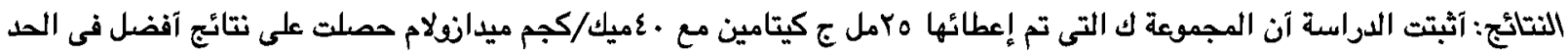

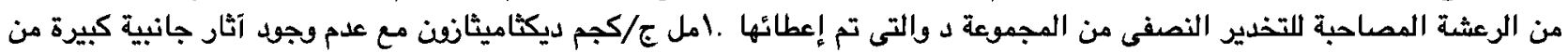
هذه الآدوية وذلك في حالات الولادة القيصرية. 